OPEN ACCESS

Edited by: Vladimir Sytnyk,

University of New South Wales,

Australia

Reviewed by:

David Lutz,

Ruhr-Universität Bochum, Germany

Sigrid A. Langhans,

Alfred I. duPont Hospital for Children,

United States

${ }^{*}$ Correspondence:

Akihiko Ito

aito@med.kindai.ac.jp

Specialty section:

This article was submitted to

Cell Adhesion and Migration,

a section of the journal

Frontiers in Cell and Developmental

Biology

Received: 27 August 2018

Accepted: 23 October 2018

Published: 06 November 2018

Citation:

Kato $T$, Hagiyama $M$ and Ito $A$ (2018) Renal ADAM10 and 17: Their Physiological and Medical Meanings.

Front. Cell Dev. Biol. 6:153.

doi: 10.3389/fcell.2018.00153

\section{Renal ADAM10 and 17: Their Physiological and Medical Meanings}

\author{
Takashi Kato', Man Hagiyama² and Akihiko Ito ${ }^{2 *}$ \\ ${ }^{1}$ Department of Cell Biology, Johns Hopkins University School of Medicine, Baltimore, MD, United States, ${ }^{2}$ Department \\ of Pathology, Kindai University School of Medicine, Osakasayama, Japan
}

A disintegrin and metalloproteinases (ADAMs) are a $\mathrm{Zn}^{2+}$-dependent transmembrane and secreted metalloprotease superfamily, so-called "molecular scissors," and they consist of an $\mathrm{N}$-terminal signal sequence, a prodomain, zinc-binding metalloprotease domain, disintegrin domain, cysteine-rich domain, transmembrane domain and cytoplasmic tail. ADAMs perform proteolytic processing of the ectodomains of diverse transmembrane molecules into bioactive mediators. This review summarizes on their most well-known members, ADAM10 and 17, focusing on the kidneys. ADAM10 is expressed in renal tubular cells and affects the expression of specific brush border genes, and its activation is involved in some renal diseases. ADAM17 is weakly expressed in normal kidneys, but its expression is markedly induced in the tubules, capillaries, glomeruli, and mesangium, and it is involved in interstitial fibrosis and tubular atrophy. So far, the various substrates have been identified in the kidneys. Shedding fragments become released ligands, such as Notch and EGFR ligands, and act as the chemoattractant factors including CXCL16. Their ectodomain shedding is closely correlated with pathological factors, which include inflammation, interstitial fibrosis, and renal injury. Also, the substrates of both ADAMs contain the molecules that play important roles at the plasma membrane, such as meaprin, E-cadherin, Klotho, and CADM1. By being released into urine, the shedding products could be useful for biomarkers of renal diseases, but ADAM10 and 17 per se are also notable as biomarkers. Furthermore, ADAM10 and/or 17 inhibitions based on various strategies such as small molecules, antibodies, and their recombinant prodomains are valuable, because they potentially protect renal tissues and promote renal regeneration. Although temporal and spatial regulations of inhibitors are problems to be solved, their inhibitors could be useful for renal diseases.

Keywords: ADAM10 metalloprotease, ADAM17, kidney, ectodomain shedding, therapeutic inhibitors

\section{ADAM10 AND ADAM17}

A disintegrin and metalloproteinases (ADAMs), a superfamily of $\mathrm{Zn}^{2+}$-dependent transmembrane and secreted metalloproteases, are responsible for a large proportion of transmembrane protein cleavage. ADAMs are approximately 750 amino acids long and evolutionarily conserved, and 22 ADAM genes have already been identified in humans. ADAMs cleave a variety of transmembrane proteins at the plasma membrane, a process which is known as ectodomain shedding (Wetzel et al., 2017). ADAM10 and 17 consist of an $\mathrm{N}$-terminal signal sequence, prodomain, metalloprotease 
(or catalytic) domain, disintegrin domain, cysteine-rich region, transmembrane region and cytoplasmic tail (Klein and Bischoff, 2011; Figure 1). In the catalytic active metalloprotease domain, a characteristic HExxHxxGxxH is commonly found ( $\mathrm{x}$ : any amino acid residue) as a zinc-binding motif (Bode et al., 1993). Although these ADAMs are close relatives, their protein sequence homology is less than $30 \%$ (Gooz, 2010).

ADAM10 is ubiquitously expressed in various mammalian cells and reacts with more than 40 substrates (Dreymueller et al., 2012; Saftig and Lichtenthaler, 2015). ADAM10 is indispensable for embryonic development, because ADAM10 knockout (KO) mice die at embryonic day 9.5 and display a defective neuronal and vascular phenotype (Hartmann et al., 2002). With respect to the kidneys, ADAM10 is expressed in renal tubular cells, and its activity affects the expression of specific brush-border genes (Cong et al., 2011). Furthermore, ADAM10 has effects some renal diseases such as lupus nephritis, arterionephrosclerosis, and DN (Gutwein et al., 2009a; Hu et al., 2016; Lattenist et al., 2016; Orme et al., 2016).

ADAM17, also named TACE (TNF- $\alpha$ converting enzyme), is the most widely studied, and releases the ectodomain of various substrates from their transmembrane preforms to produce active soluble ligands. After ectodomain shedding, these ligands bind to receptors, which lead to downstream signaling. ADAM17 is widely expressed in various tissues including the kidney, and its expression changes during embryonic development and adult life (Black et al., 1997). Especially, ADAM17 is required for normal development, as its $\mathrm{KO}$ mice die during late development or soon after birth (Peschon et al., 1998). Since ADAM17 KO mice have a similar phenotype to EGFR KO mice, defects of the eyes, skin, heart, lungs, and hair (Miettinen et al., 1995), the precursor forms of the EGFR ligands are likely to be the main substrates of ADAM17. In addition, many reports suggest critical roles of ADAM17 in immunity, inflammation, and bone formation (Scheller et al., 2011; Dreymueller et al., 2012; Rose-John, 2013). ADAM17 is weakly expressed in proximal convoluted tubules (PCT), peritubular capillaries, glomerular endothelium, and podocytes in normal kidneys (Mulder et al., 2012; Perna et al., 2017). However, in the presence of interstitial fibrosis and tubular atrophy, ADAM17 expression is markedly upregulated in the tubules, capillaries, glomeruli, and in mesangium de novo.

\section{SUBSTRATES OF ADAM10 AND 17 IN KIDNEYS (SUMMARIZED IN TABLE 1)}

\section{Cell Adhesion Molecule 1 (CADM1)}

Cell adhesion molecule 1 (CADM1) is an intercellular adhesion molecule that belongs to the immunoglobulin (Ig) superfamily, and it is localized on the lateral cell membrane and mediates neighboring cell-cell binding (Murakami, 2005; Ito et al., 2012). It functions by transmitting cell attachment signals to promote actin reorganization in the cytoplasm (Kato et al., 2018). Various types of epithelial cells express CADM1, including pulmonary cells and renal distal tubules (Nagata et al., 2012; Kato et al., 2018). CADM1 is cleaved at its ectodomain, yielding a C-terminal fragment, $\alpha \mathrm{CTF}$ (Mimae et al., 2014). ADAM10-dependent CADM1 shedding occurs in emphysematous lungs, and $\alpha \mathrm{CTF}$ contributes to apoptosis of lung epithelial cells (Nagara et al., 2012; Mimae et al., 2014). Similarly, CADM1 $\alpha$-shedding and $\alpha$ CTF enhancement were found in human nephropathies, such as arterionephrosclerosis (AS) and diabetic nephropathy (DN) (Kato et al., 2018). In particular, reduction of the full-length CADM1 (FLCADM1) level was correlated with tubular epithelial cell (TEC) apoptosis and increases of blood urea nitrogen (BUN) and serum creatinine (sCre). By conducting the in vitro studies, it may be found that CADM1 ectodomain shedding could contribute to the development of chronic kidney disease (CKD).

\section{E-cadherin}

E-cadherin forms adherens junctions between areas of cellcell contact through its ectodomain, and it plays crucial roles in the integrity of cellular polarity and cell-cell adhesions (Gall and Frampton, 2013). It can be removed from the cell surface by proteolytic cleavage as soluble E-cadherin (sE-cad), which has been reported in patients with organ failure. ADAM10 is one of several proteases that cleave E-cadherin (Crawford et al., 2009; Ma et al., 2016). The increased shedding of E-cadherin was blocked by ADAM10 inhibition (Xu et al., 2015). The effects of ADAM10 activation on E-cadherin shedding was actually reported in ADPKD (autosomal dominant polycystic kidney disease). $P k d 1$ (an ADPKD responsible gene) mutation or deletion promotes the maturation of ADAM10 via G $\alpha 12$ activation, which increases E-cadherin shedding and results in the cystogenesis of renal TECs.

\section{CXCL16}

CXCL16 not only functions as an adhesion molecule for CXCR6, but also plays an important role as a scavenger receptor for oxidized low-density lipoprotein (oxLDL) (Minami et al., 2001; Shimaoka et al., 2004; Gutwein et al., 2009b). The human kidneys highly express CXCL16 mainly in the distal convoluted tubule (DCT), connecting tubule (CNT), and collecting duct, and CXCL16 and ADAM10 are also expressed in podocytes (Gutwein et al., 2009b). Elevated CXCL16 cleavage was accompanied by increased levels of oxLDL in an atherosclerosis and CKD model (Okamura et al., 2007). ADAM10 and 17 are mainly involved in CXCL16 release from the cell membrane (Abel et al., 2004; Gough et al., 2004). Thus, both ADAMs promoted the accumulation of oxLDL, which activates proinflammatory pathways, and then causes collagen synthesis and fibrosis. The increase of urinary CXCL16 has been detected in patients with acute tubular necrosis or with lupus nephritis (Wu et al., 2007; Schramme et al., 2008), revealing that CXCL16 could be a useful biomarker for these diseases. A soluble form of CXCL16, proteolytically released, acts as a chemotactic factor. Renal allograft biopsies with acute interstitial rejection showed increased ADAM10 expression. Thus, CXCL16 and ADAM10 are involved in the recruitment of $\mathrm{T}$ cells to the kidney and play a 


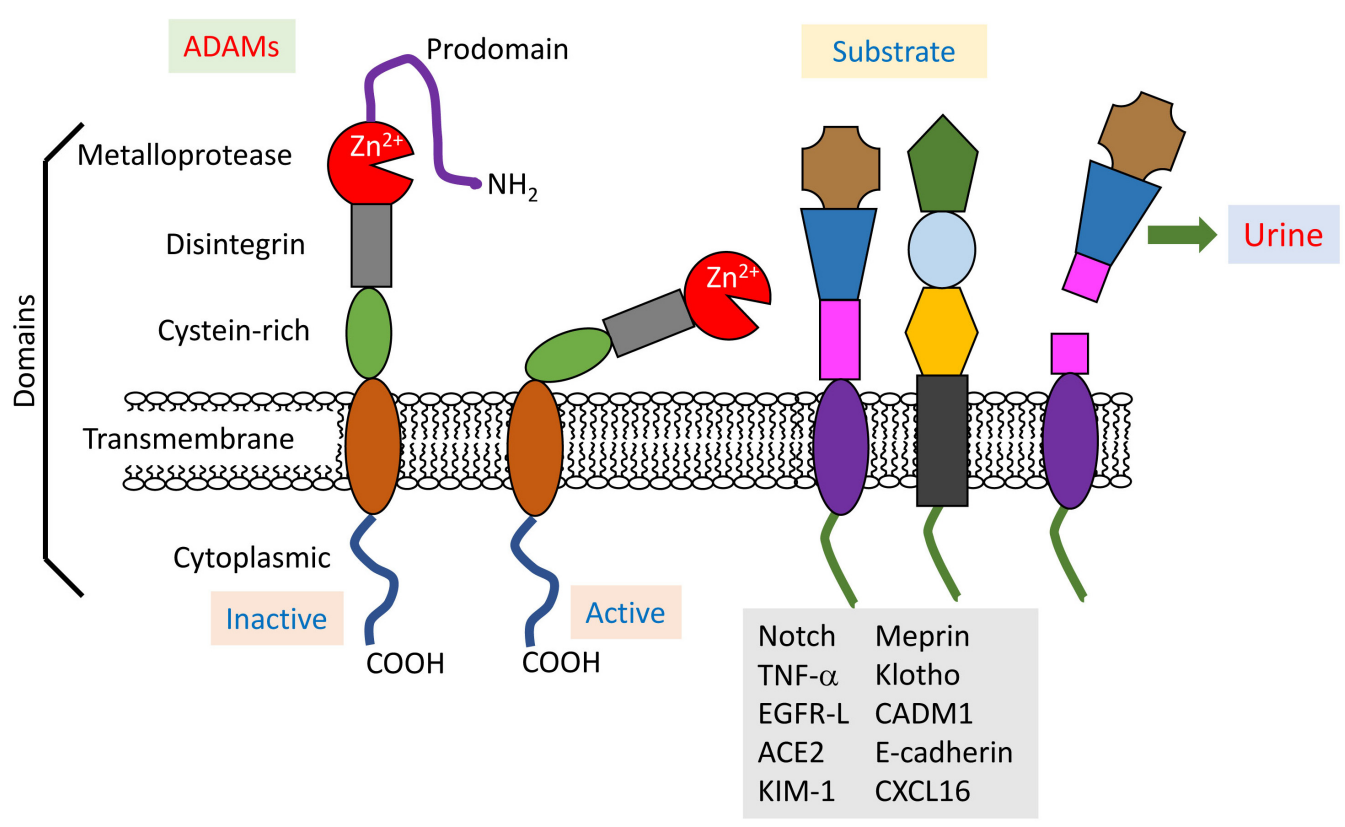

FIGURE 1 | Structure and physiopathology of ADAMs. ADAMs display common domains (prodomain, metalloprotease, disintegrin, cysteine-rich, transmembrane, and cytoplasmic), and their activities are regulated by the prodomain. Active ADAMs cleave various membranous proteins as substrates in the kidneys. Some shedding fragments are detected in urine, and thus useful for the diagnosis of renal injuries.

TABLE 1 | Substrates for ADAM 10 and 17 in the kidneys.

\begin{tabular}{|c|c|c|}
\hline Substrates & ADAMs & Associated diseases \\
\hline CADM1 & 10 & $\begin{array}{l}\text { Diabetic nephropathy, } \\
\text { arterionephroscrelosis }\end{array}$ \\
\hline E-cadherin & 10 & $\begin{array}{l}\text { Autosomal dominant polycystic kidney } \\
\text { disease }\end{array}$ \\
\hline CXCL16 & 10 & Lupus nephritis, acute tubular necrosis \\
\hline TNF- $\alpha$ & 17 & $\begin{array}{l}\text { Lupus nephritis, diabetic nephropathy, } \\
\text { acute kidney injury }\end{array}$ \\
\hline EGFR ligands & 17 & Renal fibrosis, polycystic kidney disease \\
\hline ACE2 & 17 & Diabetic nephropathy \\
\hline $\mathrm{KIM}-1$ & 17 & Acute kidney injury \\
\hline Notch & 10,17 & $\begin{array}{l}\text { Renal fibrosis, glomerulosclerosis, } \\
\text { diabetic nephropathy }\end{array}$ \\
\hline Meprin & 10,17 & Acute kidney injury \\
\hline Klotho & 10,17 & Hyperphosphatemia \\
\hline
\end{tabular}

substantive role in inflammatory renal diseases (Schramme et al., 2008).

\section{Tumor Necrosis Factor (TNF)- $\alpha$}

Proinflammatory tumor necrosis factor (TNF)- $\alpha$ belongs to a family of both soluble and cell-bound cytokines, and it is produced by immune cells and vascular endothelial cells, but also renal TECs and mesangial cells (Mehaffey and Majid, 2017). TNF- $\alpha$ and its receptors may be related to kidney injury (Ernandez and Mayadas, 2009). The involvement of TNF- $\alpha$ in renal injuries has been suggested in the presence of various renal injuries, such as lupus nephritis, DN, acute kidney injury (AKI), cisplatin-induced renal injury, renal ischemia/reperfusion injury, and kidney allograft rejection (Sanchez-Niño et al., 2010). TNF- $\alpha$ activation is closely correlated with ADAM17's activity in the kidney. Actually, TNF- $\alpha$ cleavage and release were significantly downregulated in proximal TEC-specific conditional ADAM17 KO mice, and they exhibited markedly suppression in renal proinflammatory markers and the infiltration of macrophages and neutrophils following renal injury (Kefaloyianni et al., 2016).

\section{Epidermal Growth Factor Receptor (EGFR) Ligands}

Two epidermal growth factor receptor (EGFR) ligands, heparinbinding (HB)-EGF and transforming growth factor (TGF)- $\alpha$, are involved in proliferative, migratory, and fibrotic responses of tubular cells. Elevated ADAM17 activity causes sustained EGFR activation and fibrosis after kidney injury (Kefaloyianni et al., 2016). The increased EGFR signaling through TGF$\alpha$ or HB-EGF was shown in several renal diseases including polycystic kidney disease (PKD) (Richards et al., 1998). In a model mouse of autosomal recessive PKD, increased TGF$\alpha$ expression was noted in the PCTs of cystic kidneys (Dell et al., 2001). Actually, an ADAM-17 inhibitor could significantly decrease cyst formation and improve the renal function (Nemo et al., 2005). Increased ADAM17 activity in the cystic kidneys, especially the collecting duct epithelial cells, leads to constitutive shedding of several growth factors, including HB-EGF and TGF$\alpha$. Their shedding maintains a higher cell proliferation rate in PKD cells. PKD cells then display increased lactate formation and 
extracellular acidification, indicative of aerobic glycolysis (Gooz et al., 2014).

\section{Angiotensin-Converting Enzyme 2 (ACE2)}

Angiotensin-converting enzyme 2, highly expressed in renal PCTs, degrades the vasoconstrictor angiotensin II (ANG II) to ANG-(1-7) (Chodavarapu et al., 2013). It is shed from renal tubular cells into the urinary space, and two enzymatically active glycosylated fragments may be enhanced via ADAM17 activation in diabetes (Xiao et al., 2014). This shedding is stimulated by high glucose and Ang II, can increase Ang II-degrading products in the urine of DN patients, and could serve as a biomarker of early kidney injury (Xiao et al., 2014). Furthermore, urinary ADAM17 and its substrate, ACE2, are increased in diabetic patients and its model mice (Chodavarapu et al., 2013; Gutta et al., 2018), and the shedding fragments could also be an early biomarker to predict DN-induced CKD.

\section{Kidney Injury Molecule-1 (KIM-1)}

Kidney injury molecule-1 is a receptor for phosphatidylserine, an efferocytosis signal on the surface of apoptotic cells that labels them for phagocytic clearance. Its expression is induced on PTECs in ischemic AKI, and KIM-1 ectodomain shedding generates a soluble fragment that serves as an important biomarker for AKI. Oxidative stress accelerated KIM-1 shedding (Gandhi et al., 2014). Of note, ADAM17 mediated this shedding of KIM-1 during injuries, and accelerated shedding inhibits efferocytosis (Gandhi et al., 2014).

\section{Notch}

Notch is a critical regulator of renal development, and its signaling is involved in both acute and chronic kidney injuries (Sweetwyne et al., 2014). Its overexpression is causally associated with fibrosis in diverse organs and tissues, especially tubulointerstitial fibrosis and glomerulosclerosis (Sweetwyne et al., 2014). Notch functions via its ligand-receptor binding, but also as ectodomain shedding fragments by ADAM10 and 17 (Brou et al., 2000; Hu and Phan, 2016). This ectodomain shedding product is further cleaved by a $\gamma$-secretase complex, and released as the intracellular domain of Notch (NICD) (Fortini, 2002; Okochi et al., 2002). NICD translocates into the nucleus and then it modifies target gene expression, mainly Hes family members, which correlates with transforming growth factor- $\beta$-mediated epithelial-mesenchymal transition (Artavanis-Tsakonas et al., 1999; Zavadil et al., 2004). Both ADAMs thus play essential roles in Notch signal activation and renal fibrosis.

\section{Meprin}

Meprins are also $\mathrm{Zn}^{2+}$-dependent metalloproteinases that are highly expressed at the brush-border membranes of the kidney and evolutionarily related to other proteases, MMPs and ADAMs (Stöcker et al., 1995), but possess unique structural and functional properties (Broder and Becker-Pauly, 2013). They can degrade numerous substrates such as basement membrane proteins (collagen, laminin, and fibronectin) and pro-cytokines, growth factors, and protein kinases (Herzog et al., 2014). Meprin A, composed of $\alpha$ and $\beta$ subunits, is anchored to the plasma membranes via the transmembrane domain of the $\beta$ subunits, and is the major form in the apical membranes of renal PCTs (Kumar and Bond, 2001; Bond et al., 2005; Sterchi et al., 2008). In IR-induced AKI, meprin $\beta$ was shed from PCT membranes, and excreted into the urine. Thus, released meprin $\beta$ may become detrimental during renal injury for its protein degradation activities. The meprin inhibitor actinonin exhibited strong protection against renal IR injury and hypoxiareoxygenation injury (Carmago et al., 2002). Actinonin protected the renal morphology and lowered BUN and sCre levels in the presence of renal sepsis (Wang et al., 2011). ADAM10 is responsible for meprin $\beta$ shedding, and thus the prevention of ADAM 10 activity could be of therapeutic benefit in AKI (Herzog et al., 2014). Also, a soluble form of meprin $\beta$ is produced and released into urine after IR injury, and thus meprin $\beta$ shedding also marked potential as a urine biomarker for renal injuries.

\section{Klotho}

Klotho is known as an anti-aging protein, and its KO mice exhibit many changes during aging including atherosclerosis and have a short lifespan (Kuro-o et al., 1997). Membrane-bound klotho is predominantly expressed in the DCT and CNT (Kuro-o et al., 1997; Li et al., 2004). The gene for mammalian KL has two transcripts that encode a long type I transmembrane protein and a short secreted-protein. The extracellular domain of longisoform $\mathrm{KL}$ is cleaved and released from the cell membrane (Matsumura et al., 1998). A key function of membrane-bound klotho is to act as an obligate cofactor for the fibroblast growth factor (FGF) receptor, thereby enhancing FGF23 signaling, and leading to enhanced phosphate excretion (Kurosu et al., 2006; Urakawa et al., 2006; Gattineni et al., 2009). ADAM10 is one candidate molecule for cleaving KL from the plasma membrane (Chen et al., 2007). Therefore, ADAM10 activation leads to the dysfunction of phosphate excretion (hyperphosphatemia).

\section{ADAM10 AND ADAM17 AS CLINICAL TARGETS}

ADAM10 and 17 are closely correlated with renal injuries including excess inflammation and tubular cell destruction. In addition to their substrates, ADAM10 and 17 per se are also important biomarkers of renal dysfunctions, such as early DN (Petrica et al., 2017; Gutta et al., 2018). Furthermore, many efforts have been made to develop strategies to block ADAM10 and 17 activities involving small molecules and monoclonal antibodies (Figure 2).

\section{Small Molecules (Hydroxamate-Based Compounds)}

Many small-molecule ADAMs inhibitors have been developed and mainly tested in experimental cancer models. ADAM10 inhibitors could exhibit potency to prevent renal injury. GI254023X is a hydroxymate-based inhibitor, which has inhibitory potential by chelating $\mathrm{Zn}^{2+}$ of the active sites 


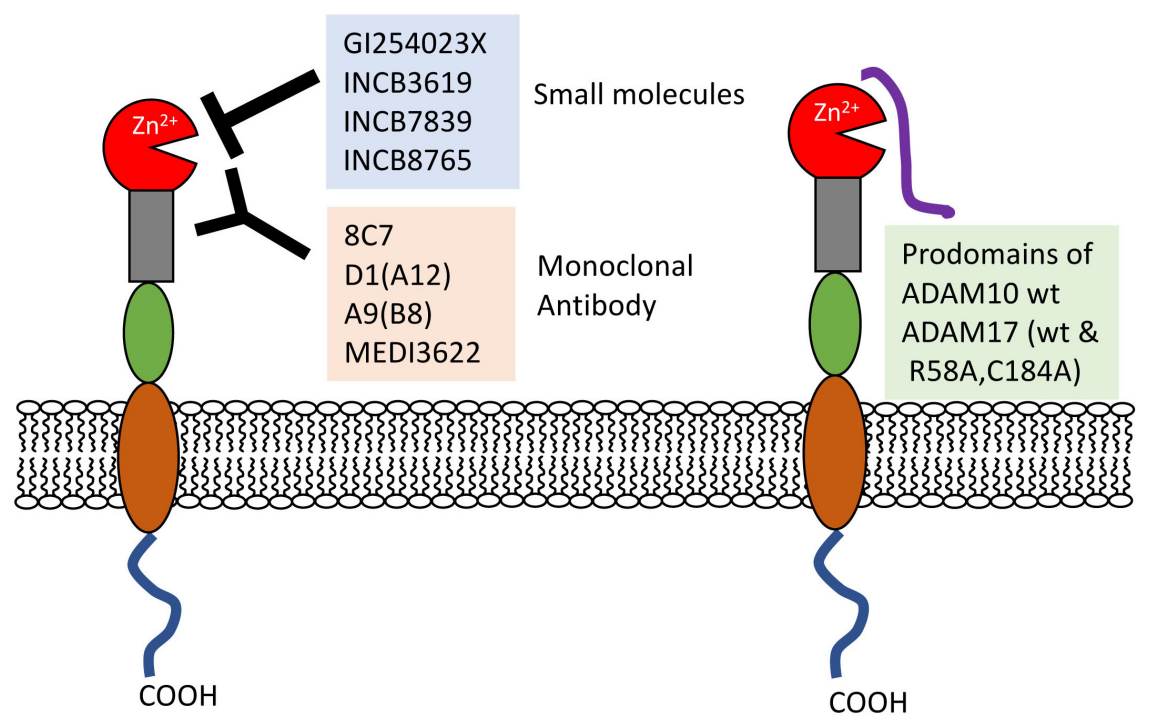

FIGURE 2 | Inhibitors of ADAM10 and prodomains 17. Small molecule inhibitors and monoclonal antibodies directly prevent the interactions between proteases and substrates. Recombinant ADAM10 and 17 prodomain (wt and its mutant) close active sites. wt, wild-type.

of protease (Dreymueller et al., 2015). GI254023X prevents ADAM10 activity more effectively than ADAM17 (Hundhausen et al., 2003; Ludwig et al., 2005). The advanced molecules INCB3619, INCB7839, and INCB8765 showed improved selectivity and bioavailability (Zhou et al., 2006; Fridman et al., 2007; Duffy et al., 2011; Mathews et al., 2011; Grabowska et al., 2012). The hydroxamate-based INCB3619 and INCB7839 inhibitors have dual effects on ADAM10 and 17 with high potency. As an ADAM17-selective inhibitor, KP457 inhibits ADAM17 with a much higher potency than ADAM10 and MMPs (Hirata et al., 2017). However, many hydroxamate-based compounds show hepatotoxicity, and so their clinical application requires close attention.

\section{Antibodies}

Monoclonal antibodies (mAb) can overcome the problems of hydroxamate-based compounds. The 8C7 mAb masked the ADAM10 recognition pocket and was more efficient than GM6001, a broad-spectrum metalloprotease inhibitor (Atapattu et al., 2012). Because of ADAM10 suppression, the 8C7 antibody could inhibit tumor growth in mouse models, particularly regrowth after chemotherapy. Similarly, targeted inhibition of active ADAM10 might be a potential therapy for some kinds of renal injuries.

Also, ADAM17 antibodies were developed. D1(A12) antibody binds to both catalytic and non-catalytic domains of ADAM17 (Tape et al., 2011). However, D1(A12) does not react with murine ADAM17, because therapeutic strategies could not be developed in experimental animal models. Thus, the antibody A9(B8) recognizes both human and murine ADAM17 and is more efficient than D1(A12) (Kwok et al., 2014). The A9(B8) antibody was investigated in a mouse model of cardiac hypertrophy by AngII infusion (Takayanagi et al., 2016). This antibody did not affect AngII-induced hypertension, but prevented endoplasmic reticulum stress and cardiovascular remodeling, showing that ADAM17 inhibitors could be beneficial for the treatment of certain hypertensive conditions. MEDI3622, another antibody for ADAM17, was produced to bind to a unique hairpin loop in the ADAM17 structure, and it was useful in an EGFR-dependent tumor model (Rios-Doria et al., 2015; Peng et al., 2016; Dosch et al., 2017).

\section{Prodomain}

The recombinant mouse ADAM10 prodomain is a potent competitive inhibitor of human ADAM10 activity with higher selectively (Moss et al., 2007).

ADAM17 prodomains could also be valuable inhibitors. A stable form of the auto-inhibitory TPD (TACE prodomain) inhibits ADAM17, but does not prevent the related ADAM10 activity (Wong et al., 2016). Furthermore, to create a more practical protein of TPD, Wong et al. produced a cleavageresistant version (R58A) and disulfide-bond lost version (C184A) of the ADAM17 prodomain, and finally created the double mutant TPD (R58A and C184A). This mutant prodomain effectively modulated TNF- $\alpha$ secretion. TPD attenuated TACEmediated disease models of sepsis, rheumatoid arthritis (RA), and inflammatory bowel disease (IBD) (Wong et al., 2016).

\section{Others}

Some natural compounds reduce ADAM10 activity. Rapamycin suppresses ADAM10 activity (Zhang et al., 2010) and prevents organ rejection following transplantation via suppressive effects on ADAM10 activity. Fish oil (FO) supplement reduces the shedding and release of transmembrane proteins from endothelial cells by ADAM10 and 17, and thus prevents 
atherogenic diseases (Speck et al., 2015). By suppressing ADAM activity, FO partly contributes to an improved endothelial barrier function and prevents lipoprotein and macrophage accumulation, although the detailed mechanisms remain unknown. Furthermore, the diterpenoid epoxide triptolide downregulates ADAM10 expression, possibly through its degradation (Soundararajan et al., 2009). In traditional Chinese medicine, triptolide has been used for centuries to treat inflammatory diseases such as RA, systemic lupus erythematosus (SLE), and ADPKD (Leuenroth et al., 2007; Wetzel et al., 2017).

Because targeted inhibition of active ADAM10 and/or 17 is expected to become a potential therapy for associated diseases, these strategies have been advanced. However, ADAM10 and 17 have many substrates with diverse functions; therefore, it is important for the temporal and spatial regulation of inhibitors to avoid undesirable side effects.

\section{REFERENCES}

Abel, S., Hundhausen, C., Mentlein, R., Schulte, A., Berkhout, T. A., Broadway, N., et al. (2004). The transmembrane CXC-chemokine ligand 16 is induced by IFN-gamma and TNF-alpha and shed by the activity of the disintegrinlike metalloproteinase ADAM10. J. Immunol. 172, 6362-6372. doi: 10.4049/ jimmunol.172.10.6362

Artavanis-Tsakonas, S., Rand, M. D., and Lake, R. J. (1999). Notch signaling: cell fate control and signal integration in development. Science 284, 770-776. doi: 10.1126/science.284.5415.770

Atapattu, L., Saha, N., Llerena, C., Vail, M. E., Scott, A. M., Nikolov, D. B., et al. (2012). Antibodies binding the ADAM10 substrate recognition domain inhibit Eph function. J. Cell Sci. 125, 6084-6093. doi: 10.1242/jcs.112631

Black, R. A., Rauch, C. T., Kozlosky, C. J., Peschon, J. J., Slack, J. L., Wolfson, M. F., et al. (1997). A metalloproteinase disintegrin that releases tumour-necrosis factor-alpha from cells. Nature 385, 729-733. doi: 10.1038/385729a0

Bode, W., Gomis-Rüth, F. X., and Stöckler, W. (1993). Astacins, serralysins, snake venom and matrix metalloproteinases exhibit identical zinc-binding environments (HEXXHXXGXXH and Met-turn) and topologies and should be grouped into a common family, the 'metzincins'. FEBS Lett. 331, 134-140. doi: 10.1016/0014-5793(93)80312-I

Bond, J. S., Matters, G. L., Banerjee, S., and Dusheck, R. E. (2005). Meprin metalloprotease expression and regulation in kidney, intestine, urinary tract infections and cancer. FEBS Lett. 579, 3317-3322. doi: 10.1016/j.febslet.2005. 03.045

Broder, C., and Becker-Pauly, C. (2013). The metalloproteases meprin $\alpha$ and meprin $\beta$ : unique enzymes in inflammation, neurodegeneration, cancer and fibrosis. Biochem. J. 450, 253-264. doi: 10.1042/BJ20121751.

Brou, C., Logeat, F., Gupta, N., Bessia, C., LeBail, O., Doedens, J. R., et al. (2000). A novel proteolytic cleavage involved in Notch signaling: the role of the disintegrin-metalloprotease TACE. Mol. Cell 5, 207-216. doi: 10.1016/S10972765(00)80417-7

Carmago, S., Shah, S. V., and Walker, P. D. (2002). Meprin, a brush-border enzyme, plays an important role in hypoxic/ischemic acute renal tubular injury in rats. Kidney Int. 61, 959-966. doi: 10.1046/j.1523-1755.2002.00209.x

Chen, C. D., Podvin, S., Gillespie, E., Leeman, S. E., and Abraham, C. R. (2007). Insulin stimulates the cleavage and release of the extracellular domain of Klotho by ADAM10 and ADAM17. Proc. Natl. Acad. Sci. U.S.A. 104, 19796-19801. doi: 10.1073/pnas.0709805104

Chodavarapu, H., Grobe, N., Somineni, H. K., Salem, E. S., Madhu, M., and Elased, K. M. (2013). Rosiglitazone treatment of type 2 diabetic $\mathrm{db} / \mathrm{db}$ mice attenuates urinary albumin and angiotensin converting enzyme 2 excretion. PLoS One 8:e62833. doi: 10.1371/journal.pone.0062833

Cong, R., Li, Y., and Biemesderfer, D. (2011). A disintegrin and metalloprotease 10 activity sheds the ectodomain of the amyloid precursor-like protein 2 and regulates protein expression in proximal tubule cells. Am. J. Physiol. Cell Physiol. 300, C1366-C1374. doi: 10.1152/ajpcell.00451.2010

\section{AUTHOR CONTRIBUTIONS}

TK conceived the idea and wrote the manuscript. MH and AI edited the manuscript and helped to improve the quality of this review paper.

\section{FUNDING}

This study was supported by Japan Society for the Promotion of Science KAKENHI grants (17K08680 to MH, and 18K07049 to AI); the Ministry of Education, Culture, Sports, Science and Technology-Supported Program for the Strategic Research Foundation at Private Universities 2015-18 (to AI); and a 21st Century Joint Research Enhancement Grant of Kindai University (to $\mathrm{AI}$ ).

Crawford, H. C., Dempsey, P. J., Brown, G., Adam, L., and Moss, M. L. (2009). ADAM10 as a therapeutic target for cancer and inflammation. Curr. Pharm. Des. 15, 2288-2299. doi: 10.2174/138161209788682442

Dell, K. M., Nemo, R., Sweeney, W. E. Jr., Levin, J. I., Frost, P., and Avner, E. D. (2001). A novel inhibitor of tumor necrosis factor-alpha converting enzyme ameliorates polycystic kidney disease. Kidney Int. 60, 1240-1248. doi: 10.1046/ j.1523-1755.2001.00963.x

Dosch, J., Ziemke, E., Wan, S., Luker, K., Welling, T., Hardiman, K., et al. (2017). Targeting ADAM17 inhibits human colorectal adenocarcinoma progression and tumor-initiating cell frequency. Oncotarget 8, 65090-65099. doi: 10.18632/ oncotarget. 17780

Dreymueller, D., Pruessmeyer, J., Groth, E., and Ludwig, A. (2012). The role of ADAM- mediated shedding in vascular biology. Eur. J. Cell Biol. 91, 472-485. doi: 10.1016/j.ejcb.2011.09.003

Dreymueller, D., Uhlig, S., and Ludwig, A. (2015). ADAM-family metalloproteinases in lung inflammation: potential therapeutic targets. Am. J. Physiol. Lung. Cell Mol. Physiol. 308, L325-L343. doi: 10.1152/ajplung.00294.2014

Duffy, M. J., Mullooly, M., O’Donovan, N., Sukor, S., Crown, J., Pierce, A., McGowan., et al. (2011). The ADAMs family of proteases: new biomarkers and therapeutic targets for cancer? Clin. Proteomics 8:9. doi: 10.1186/1559-0275-8-9

Ernandez, T., and Mayadas, T. N. (2009). Immunoregulatory role of TNFalpha in inflammatory kidney diseases. Kidney Int. 76, 262-276. doi: 10.1038/ki. 2009.142 .

Fortini, M. E. (2002). Gamma-secretase-mediated proteolysis in cell-surfacereceptor signalling. Nat. Rev. Mol. Cell Biol. 3, 673-684. doi: 10.1038/nr m910

Fridman, J. S., Caulder, E., Hansbury, M., Liu, X., Yang, G., Wang, Q., et al. (2007). Selective inhibition of ADAM metalloproteases as a novel approach for modulating ErbB pathways in cancer. Clin. Cancer Res. 13, 1892-1902. doi: 10.1158/1078-0432.CCR-06-2116

Gall, T. M., and Frampton, A. E. (2013). Gene of the month: E-cadherin (CDH1). J. Clin. Pathol. 66, 928-932. doi: 10.1136/jclinpath-2013-201768

Gandhi, R., Yi, J., Ha, J., Shi, H., Ismail, O., Nathoo, S., et al. (2014). Accelerated receptor shedding inhibits kidney injury molecule-1 (KIM-1)mediated efferocytosis. Am. J. Physiol. Ren. Physiol. 307, F205-F221. doi: 10. 1152/ajprenal.00638.2013

Gattineni, J., Bates, C., Twombley, K., Dwarakanath, V., Robinson, M. L., Goetz, R., et al. (2009). FGF23 decreases renal NaPi-2a and NaPi-2c expression and induces hypophosphatemia in vivo predominantly via FGF receptor $1 . \mathrm{Am}$. J. Physiol. Ren. Physiol. 297, F282-F291. doi: 10.1152/ajprenal.90742.2008

Gooz, M. (2010). ADAM-17: the enzyme that does it all. Crit. Rev. Biochem. Mol. Biol. 45, 146-169. doi: 10.3109/104092310036 28015

Gooz, M., Maldonado, E. N., Dang, Y., Amria, M. Y., Higashiyama, S., Abboud, H. E., et al. (2014). ADAM17 promotes proliferation of collecting duct kidney epithelial cells through ERK activation and increased glycolysis in polycystic 
kidney disease. Am. J. Physiol. Ren. Physiol. 307, F551-F559. doi: 10.1152/ ajprenal.00218.2014

Gough, P. J., Garton, K. J., Wille, P. T., Rychlewski, M., Dempsey, P. J., and Raines, E. W. (2004). A disintegrin and metalloproteinase 10-mediated cleavage and shedding regulates the cell surface expression of CXC chemokine ligand 16. J. Immunol. 172, 3678-3685. doi: 10.4049/jimmunol.172.6.3678

Grabowska, M. M., Sandhu, B., and Day, M. L. (2012). EGF promotes the shedding of soluble E-cadherin in an ADAM10-dependent manner in prostate epithelial cells. Cell. Signal. 24, 532-538. doi: 10.1016/j.cellsig.2011.10.004

Gutta, S., Grobe, N., Kumbaji, M., Osman, H., Saklayen, M., Li, G., et al. (2018). Increased urinary angiotensin converting enzyme 2 (ACE2) and neprilysin (NEP) in type 2 diabetic patients. Am. J. Physiol. Ren. Physiol. 315, F263-F274. doi: 10.1152/ajprenal.00565.2017

Gutwein, P., Abdel-Bakky, M. S., Doberstein, K., Schramme, A., Beckmann, J., Schaefer, L., et al. (2009a). CXCL16 and oxLDL are induced in the onset of diabetic nephropathy. J. Cell Mol. Med. 13, 3809-3825. doi: 10.1111/j.15824934.2009.00761.x

Gutwein, P., Abdel-Bakky, M. S., Schramme, A., Doberstein, K., Kämpfer-Kolb, N., Amann, K., et al. (2009b). CXCL16 is expressed in podocytes and acts as a scavenger receptor for oxidized low-density lipoprotein. Am. J. Pathol. 174, 2061-2072. doi: 10.2353/ajpath.2009.080960

Hartmann, D., de Strooper, B., Serneels, L., Craessaerts, K., Herreman, A., Annaert, W., et al. (2002). The disintegrin/metalloprotease ADAM 10 is essential for Notch signalling but not for alpha-secretase activity in fibroblasts. Hum. Mol. Genet. 11, 2615-2624. doi: 10.1093/hmg/11.21.2615

Herzog, C., Haun, R. S., Ludwig, A., Shah, S. V., and Kaushal, G. P. (2014). ADAM10 is the major sheddase responsible for the release of membraneassociated meprin A. J. Biol. Chem. 289, 13308-13322. doi: 10.1074/jbc.M114. 559088

Hirata, S., Murata, T., Suzuki, D., Nakamura, S., Jono-Ohnishi, R., Hirose, H., et al. (2017) Selective Inhibition of ADAM17 efficiently mediates glycoprotein ib $\alpha$ retention during ex vivo generation of human induced pluripotent stem cellderived platelets. Stem Cells Transl. Med. 6, 720-730. doi: 10.5966/sctm.20160104

Hu, B., and Phan, S. H. (2016). Notch in fibrosis and as a target of anti-fibrotic therapy. Pharmacol. Res. 108, 57-64. doi: 10.2353/ajpath.2009.080960

Hu, Z.B., Chen, Y., Gong, Y.X., Gao, M., Zhang, Y., Wang, G.H., et al. (2016) Activation of the CXCL16/CXCR6 pathway by inflammation contributes to atherosclerosis in patients with end-stage renal disease. Int. J. Med. Sci. 13, 858-867. doi: 10.7150/ijms.16724

Hundhausen, C., Misztela, D., Berkhout, T. A., Broadway, N., Saftig, P., Reiss, K., et al. (2003). The disintegrin-like metalloproteinase ADAM10 is involved in constitutive cleavage of CX3CL1(fractalkine) and regulates CX3CL1-mediated cell-cell adhesion. Blood 102, 1186-1195. doi: 10.1182/blood-2002-12-3775

Ito, A, Ichiyanagi, N., Ikeda, Y., Hagiyama, M., Inoue, T., Kimura, K. B., et al. (2012). Adhesion molecule CADM1 contributes to gap junctional communication among pancreatic islet $\alpha$-cells and prevents their excessive secretion of glucagon. Islets 4, 49-55. doi: 10.4161/isl.18675

Kato, T., Hagiyama, M., Takashima, Y., Yoneshige, A., and Ito, A. (2018). Cell adhesion molecule-1 shedding induces apoptosis of renal epithelial cells and exacerbates human nephropathies. Am. J. Physiol. Ren. Physiol. 314, F388-F398. doi: 10.1152/ajprenal.00385.2017

Kefaloyianni, E., Muthu, M. L., Kaeppler, J., Sun, X., Sabbisetti, V., Chalaris, A., et al. (2016). ADAM17 substrate release in proximal tubule drives kidney fibrosis. JCI Insight 1:e87023. doi: 10.1172/jci.insight.87023

Klein, T., and Bischoff, R. (2011). Active metalloproteases of the A Disintegrin and Metalloprotease (ADAM) family: biological function and structure. J. Proteome Res. 10, 17-33. doi: 10.1021/pr100556z

Kumar, J. M., and Bond, J. S. (2001). Developmental expression of meprin metalloprotease subunits in ICR and $\mathrm{C} 3 \mathrm{H} / \mathrm{He}$ mouse kidney and intestine in the embryo, postnatally and after weaning. Biochim. Biophys. Acta 1518, 106-114. doi: 10.1016/S0167-4781(01)00188-9

Kuro-o, M, Matsumura Y, Aizawa H, Kawaguchi H, Suga T, Utsugi T, et al. (1997). Mutation of the mouse klotho gene leads to a syndrome resembling ageing. Nature 390. 45-51. doi: 10.1038/36285

Kurosu, H., Ogawa, Y., Miyoshi, M., Yamamoto, M., Nandi, A., Rosenblatt, K. P., et al. (2006). Regulation of fibroblast growth factor-23 signaling by klotho. J. Biol. Chem. 281, 6120-6123. doi: 10.1074/jbc.C500457200
Kwok, H. F., Botkjaer, K. A., Tape, C. J., Huang, Y., McCafferty, J., and Murphy, G. (2014). Development of a 'mouse and human cross-reactive' affinity-matured exosite inhibitory human antibody specific to TACE (ADAM17) for cancer immunotherapy. Protein Eng. Des. Sel. 27, 179-190. doi: 10.1093/protein/ gzu010.

Lattenist, L., Ochodnick $\iota$, P., Ahdi, M., Claessen, N., Leemans, J. C., Satchell, S. C., et al. (2016). Renal endothelial protein $C$ receptor expression and shedding during diabetic nephropathy. J. Thromb. Haemost. 14, 1171-1182. doi: 10.1111/ jth. 13315

Leuenroth, S. J., Okuhara, D., Shotwell, J. D., Markowitz, G. S., Yu, Z., Somlo, S., et al. (2007). Triptolide is a traditional Chinese medicine-derived inhibitor of polycystic kidney disease. Proc. Natl. Acad. Sci. U.S.A. 104, 4389-4394. doi: 10.1073/pnas.0700499104

Li, S. A., Watanabe, M., Yamada, H., Nagai, A., Kinuta, M., and Takei, K. (2004). Immunohistochemical localization of Klotho protein in brain, kidney, and reproductive organs of mice. Cell Struct. Funct. 29, 91-99. doi: 10.1247/csf. 29.91

Ludwig, A., Hundhausen, C., Lambert, M. H., Broadway, N., Andrews, R. C., Bickett, D. M., et al. (2005). Metalloproteinase inhibitors for the disintegrin-like metalloproteinases ADAM10 and ADAM17 that differentially block constitutive and phorbol ester-inducible shedding of cell surface molecules. Comb. Chem. High Throughput Screen. 8, 161-171. doi: 10.2174/ 1386207053258488

Ma, B., Zhang, H. Y., Bai, X., Wang, F., Ren, X. H., Zhang, L., et al. (2016). ADAM10 mediates the cell invasion and metastasis of human esophageal squamous cell carcinoma via regulation of E-cadherin activity. Oncol. Rep. 35, 2785-2794. doi: 10.3892/or.2016.4667

Mathews, J. A., Ford, J., Norton, S., Kang, D., Dellinger, A., Gibb, D. R., et al. (2011). A potential new target for asthma therapy: a disintegrin and metalloprotease 10 (ADAM10) involvement in murine experimental asthma. Allergy 66, 1193-1200. doi: 10.1111/j.1398-9995.2011. 02614.x

Matsumura, Y., Aizawa, H., Shiraki-Iida, T., Nagai, R., Kuro-o, M., and Nabeshima, Y. (1998). Identification of the human klotho gene and its two transcripts encoding membrane and secreted klotho protein. Biochem. Biophys. Res. Commun. 242, 626-630. doi: 10.1006/bbrc.1997.8019

Mehaffey, E., and Majid, D. S .A. (2017). Tumor necrosis factor- $\alpha$, kidney function, and hypertension. Am. J. Physiol. Renal. Physiol. 313, F1005-F1008. doi: 10.1152/ajprenal.00535. 2016

Miettinen, P. J., Berger, J. E., Meneses, J., Phung, Y., Pedersen, R. A., Werb, Z., et al. (1995). Epithelial immaturity and multiorgan failure in mice lacking epidermal growth factor receptor. Nature 376, 337-341. doi: 10.1038/376337a0

Mimae, T., Hagiyama, M., Inoue, T., Yoneshige, A., Kato, T., Okada, M., et al. (2014). Increased ectodomain shedding of lung epithelial cell adhesion molecule 1 as a cause of increased alveolar cell apoptosis in emphysema. Thorax 69, 223-231. doi: 10.1136/thoraxjnl-2013-203867

Minami, M., Kume, N., Shimaoka, T., Kataoka, H., Hayashida, K., Akiyama, Y., et al. (2001). Expression of SR-PSOX, a novel cell-surface scavenger receptor for phosphatidylserine and oxidized LDL in human atherosclerotic lesions. Arterioscler. Thromb. Vasc. Biol. 21, 1796-1800. doi: 10.1161/hq1001. 096652

Moss, M. L., Bomar, M., Liu, Q., Sage, H., Dempsey, P., Lenhart, P. M., et al. (2007). The ADAM10 prodomain is a specific inhibitor of ADAM10 proteolytic activity and inhibits cellular shedding events. J. Biol. Chem. 282, 35712-35721. doi: 10.1074/jbc.M703231200

Mulder, G. M., Melenhorst, W. B., Celie, J. W., Kloosterhuis, N. J., Hillebrands, J. L., Ploeg, R. J., et al. (2012). ADAM17 up-regulation in renal transplant dysfunction and non-transplant-related renal fibrosis. Nephrol. Dial. Transplant. 27, 2114-2122. doi: 10.1093/ndt/gfr583

Murakami, Y. (2005). Involvement of a cell adhesion molecule, TSLC1/IGSF4, in human oncogenesis. Cancer Sci. 96, 543-552. doi: 10.1111/j.1349-7006.2005. 00089.x

Nagara, Y., Hagiyama, M., Hatano, N., Futai, E., Suo, S., Takaoka, Y., et al. (2012). Tumor suppressor cell adhesion molecule 1 (CADM1) is cleaved by a disintegrin and metalloprotease 10 (ADAM10) and subsequently cleaved by $\gamma$-secretase complex. Biochem. Biophys. Res. Commun. 417, 462-467. doi: 10. 1016/j.bbrc.2011.11.140 
Nagata, M., Sakurai-Yageta, M., Yamada, D., Goto, A., Ito, A., Fukuhara, H., et al. (2012). Aberrations of a cell adhesion molecule CADM4 in renal clear cell carcinoma. Int. J. Cancer 130, 1329-1337. doi: 10.1002/ijc.26160

Nemo, R., Murcia, N., and Dell, K. M. (2005). Transforming growth factor alpha (TGF-alpha) and other targets of tumor necrosis factor-alpha converting enzyme (TACE) in murine polycystic kidney disease. Pediatr. Res. 57, 732-737. doi: 10.1203/01.PDR.0000159513.51898.60

Okamura, D. M., López-Guisa, J. M., Koelsch, K., Collins, S., and Eddy, A. A. (2007). Atherogenic scavenger receptor modulation in the tubulointerstitium in response to chronic renal injury. Am. J. Physiol. Ren. Physiol. 293, F575-F585. doi: 10.1152/ajprenal.00063.2007

Okochi, M., Steiner, H., Fukumori, A., Tanii, H., Tomita, T., Tanaka, T., et al. (2002). Presenilins mediate a dual intramembranous gamma-secretase cleavage of Notch-1. EMBO J. 21, 5408-5416. doi: 10.1093/emboj/cdf541

Orme, J. J., Du, Y., Vanarsa, K., Mayeux, J., Li, L., Mutwally, A., et al. (2016). Heightened cleavage of Axl receptor tyrosine kinase by ADAM metalloproteases may contribute to disease pathogenesis in SLE. Clin. Immunol. 169, 58-68. doi: 10.1016/j.clim.2016.05.011.

Peng, L., Cook, K., Xu, L., Cheng, L., Damschroder, M., Gao, C., et al. (2016). Molecular basis for the mechanism of action of an anti-TACE antibody. MAbs 28, 1598-1605. doi: 10.1080/19420862.2016.1226716

Perna, A. F., Pizza, A., Di, Nunzio A., Bellantone, R., Raffaelli, M., Cicchella, T., et al. (2017). ADAM17, a new player in the pathogenesis of chronic kidney disease-mineral and bone disorder. J. Ren. Nutr. 27, 453-457. doi: 10.1053/j. jrn.2017.05.007.

Peschon, J. J., Slack, J. L., Reddy, P., Stocking, K. L., Sunnarborg, S. W., Lee, D. C., et al. (1998). An essential role for ectodomain shedding in mammalian development. Science 282, 1281-1284. doi: 10.1126/science.282.5392.1281

Petrica, L., Ursoniu, S., Gadalean F., Vlad, A., Gluhovschi, G., and Dumitrascu, V. et al. (2017). Urinary podocyte-associated mRNA levels correlate with proximal tubule dysfunction in early diabetic nephropathy of type 2 diabetes mellitus. Diabetol. Metab. Syndr. 9:31. doi: 10.1186/s13098-017-0228-y.

Richards, W. G., Sweeney, W. E., Yoder, B. K., Wilkinson, J. E., Woychik, R. P., and Avner, E. D. (1998). Epidermal growth factor receptor activity mediates renal cyst formation in polycystic kidney disease. J. Clin. Invest. 101, 935-939. doi: 10.1172/JCI2071

Rios-Doria, J., Sabol, D., Chesebrough, J., Stewart, D., Xu, L., Tammali, R., et al. (2015). Monoclonal antibody to ADAM17 inhibits tumor growth by inhibiting EGFR and non-EGFR-mediated pathways. Mol. Cancer Ther. 14, 1637-1649. doi: 10.1158/1535-7163.MCT-14-1040

Rose-John, S. (2013). ADAM17, shedding, TACE as therapeutic targets. Pharmacol. Res. 71, 19-22. doi: 10.1016/j.phrs.2013.01.012

Saftig, P., and Lichtenthaler, S. F. (2015). The alpha secretase ADAM10: a metalloprotease with multiple functions in the brain. Prog. Neurobiol. 135, 1-20. doi: 10.1016/j.pneurobio.2015.10.003

Sanchez-Niño M. D., Benito-Martin, A., Gonçalves, S., Sanz, A. B., Ucero, A. C., Izquierdo, M. C., et al. (2010). TNF superfamily: a growing saga of kidney injury modulators. Mediators Inflamm. 2010:182958. doi: 10.1155/2010/182958

Scheller, J., Chalaris, A., Garbers, C., and Rose-John, S. (2011). ADAM17: a molecular switch to control inflammation and tissue regeneration. Trends Immunol. 32, 380-387. doi: 10.1016/j.it.2011.05.005

Schramme, A., Abdel-Bakky, M. S., Gutwein, P., Obermüller, N., Baer, P. C., Hauser, I. A., et al. (2008). Characterization of CXCL16 and ADAM10 in the normal and transplanted kidney. Kidney Int. 74, 328-338. doi: 10.1038/ki. 2008.181

Shimaoka, T., Nakayama, T., Hieshima, K., Kume, N., Fukumoto, N., Minami, M., et al. (2004). Chemokines generally exhibit scavenger receptor activity through their receptor-binding domain. J. Biol. Chem. 279, 26807-26810. doi: 10.1074/ jbc.C400163200

Soundararajan, R., Sayat, R., Robertson, G. S., and Marignani, P. A. (2009). Triptolide: an in- hibitor of a disintegrin and metalloproteinase 10 (ADAM10) in cancer cells. Cancer Biol. Ther. 8, 2054-2062. doi: 10.4161/cbt.8.21.9803

Speck, N., Brandsch, C., Schmidt, N., Yazdekhasti, N., Hirche, F., Lucius, R., et al. (2015). The antiatherogenic effect of fish oil in male mice is associated with a diminished release of endothelial ADAM17 and ADAM10 substrates. J. Nutr. 145, 1218-1226. doi: 10.3945/jn.115.211375.

Sterchi, E.E., Stöcker, W., and Bond, J.S. (2008) Meprins, membrane-bound and secreted astacin metalloproteinases. Mol. Aspects Med. 29, 309-328. doi: 10. 1016/j.mam.2008.08.002

Stöcker, W., Grams, F., Baumann, U., Reinemer, P., Gomis-Rüth, F. X., McKay, D. B., et al. (1995). The metzincins-topological and sequential relations between the astacins, adamalysins, serralysins, and matrixins (collagenases) define a superfamily of zinc-peptidases. Protein Sci. 4, 823-840. doi: 10.1002/pro. 5560040502

Sweetwyne, M. T., Tao, J., and Susztak, K. (2014). Kick it up a notch: notch signaling and kidney fibrosis. Kidney Int. Suppl. 4, 91-96. doi: 10.1038/kisup.2014.17

Takayanagi, T., Forrester, S. J., Kawai, T., Obama, T., Tsuji, T., Elliott, K. J., et al. (2016). Vascular ADAM17 as a novel therapeutic target in mediating cardiovascular hypertrophy and perivascular fibrosis induced by angiotensin II. Hypertension 68, 949-955. doi: 10.1161/HYPERTENSIONAHA.116.07620

Tape, C. J., Willems, S. H., Dombernowsky, S. L., Stanley, P. L., Fogarasi, M., Ouwehand, W., et al. (2011). Cross-domain inhibition of TACE ectodomain. Proc. Natl. Acad. Sci. U.S.A. 108, 5578-5583. doi: 10.1073/pnas.101706 7108.

Urakawa, I., Yamazaki, Y., Shimada, T., Iijima, K., Hasegawa, H., Okawa, K., et al. (2006). Klotho converts canonical FGF receptor into a specific receptor for FGF23. Nature 444, 770-774. doi: 10.1038/nature05315

Wang, Z., Herzog, C., Kaushal, G. P., Gokden, N., and Mayeux, P. R. (2011). Actinonin, a meprin A inhibitor, protects the renal microcirculation during sepsis. Shock 35, 141-147. doi: 10.1097/SHK.0b013e3181ec39cc.

Wetzel, S., Seipold, L., and Saftig, P. (2017). The metalloproteinase ADAM10: a useful therapeutic target? Biochim. Biophys. Acta. 1864, 2071-2081. doi: 10. 1016/j.bbamcr.2017.06.005.

Wong, E., Cohen, T., Romi, E., Levin, M., Peleg, Y., Arad, U., et al. (2016). Harnessing the natural inhibitory domain to control TNF $\alpha$ converting enzyme (TACE) activity in vivo. Sci. Rep. 16:35598. doi: 10.1038/srep35598.

Wu, T., Xie, C., Wang, H. W., Zhou, X. J., Schwartz, N., Calixto, S., et al. (2007). Elevated urinary VCAM-1, P-selectin, soluble TNF receptor-1, and CXC chemokine ligand 16 in multiple murine lupus strains and human lupus nephritis. J. Immunol. 179, 7166-7175. doi: 10.4049/jimmunol.179.10.7166

Xiao, F., Zimpelmann, J., Agaybi, S., Gurley, S. B., Puente, L., and Burns, K. D. (2014). Characterization of angiotensin-converting enzyme 2 ectodomain shedding from mouse proximal tubular cells. PLoS One 9:e85958. doi: 10.1371/ journal.pone.0085958

Xu, J. X., Lu, T. S., Li, S., Wu, Y., Ding, L., Denker, B. M., et al. (2015). Polycystin-1 and $\mathrm{G} \alpha 12$ regulate the cleavage of E-cadherin in kidney epithelial cells. Physiol. Genomics 47, 24-32. doi: 10.1152/physiolgenomics.00090.2014.

Zavadil, J., Cermak, L., Soto-Nieves, N., and Böttinger, E. P. (2004). Integration of TGF-beta/Smad and Jagged1/Notch signalling in epithelial-to-mesenchymal transition. EMBO J. 23, 1155-1165. doi: 10.1038/sj.emboj.7600069

Zhang, S., Salemi, J., Hou, H., Zhu, Y., Mori, T., Giunta, B., et al. (2010). Rapamycin promotes $\beta$-amyloid production via ADAM-10 inhibition. Biochem. Biophys. Res. Commun. 398, 337-341. doi: 10.1016/j.bbrc.2010.06.017

Zhou, B. B., Peyton, M., He, B., Liu, C., Girard, L., Caudler, E., et al. (2006). Targeting ADAM-mediated ligand cleavage to inhibit HER3 and EGFR pathways in non-small cell lung cancer. Cancer Cell 10, 39-50. doi: 10.1016/j. ccr.2006.05.024

Conflict of Interest Statement: The authors declare that the research was conducted in the absence of any commercial or financial relationships that could be construed as a potential conflict of interest.

Copyright (c) 2018 Kato, Hagiyama and Ito. This is an open-access article distributed under the terms of the Creative Commons Attribution License (CC BY). The use, distribution or reproduction in other forums is permitted, provided the original author(s) and the copyright owner(s) are credited and that the original publication in this journal is cited, in accordance with accepted academic practice. No use, distribution or reproduction is permitted which does not comply with these terms. 